\title{
遠心場掘削シミュレーターを用いた簡易な 地山補強の斜面安定効果に関する遠心模型実験
}

\author{
伊藤 和也 1 -林 豪人 $2 \cdot$ 吉川 直孝 $3 \cdot$ 平岡 伸隆 4 ・ 小浪 岳治 5 \\ 1正会員 東京都市大学准教授 工学部都市工学科（ \\ (元 (独)労働安全衛生総合研究所 建設安全研究グループ) \\ E-mail: itok@tcu.ac.jp \\ 2正会員＼cjkstart岡三リビック(株) 技術開発部（テ108-0075 東京都港区港南1丁目8番27号 日新ビル10F） \\ E-mail: hayashi.taketo@okasanlivic.co.jp \\ 3正会員 (独)労働者健康安全機構 労働安全衛生総合研究所 建設安全研究グループ \\ （干204-0024 東京都清瀬市梅園1-4-6） \\ E-mail:kikkawa@s.jniosh.johas.go.jp \\ 4正会員 (独)労働者健康安全機構 労働安全衛生総合研究所 建設安全研究グループ \\ ( ₹204-0024 東京都清瀬市梅園1-4-6) \\ E-mail: hiraoka@s.jniosh.johas.go.jp \\ 5正会員 岡三リビック(株) 技術開発部（干108-0075 東京都港区港南1丁目8番27号 日新ビル10F） \\ E-mail: konami@okasanlivic.co.jp
}

\begin{abstract}
本研究は，斜面崩壊によるリスクが高いと判断された斜面を簡易的かつ仮設的に補強する地山補強土工 法について掘削除荷過程における斜面安定効果を把握するために，新たに開発した遠心場掘削シミュレー ターを用いて遠心場掘削実験を実施した。斜面勾配の違いや補強材の有無等を変化させた斜面の掘削段階 毎のせん断ひずみ分布や変形挙動を各種変位計測およびPIV画像解析を用いて検討した。その結果，段階 的な切土掘削作業を行うことにより法尻部の位置が変化することからひずみが集中せずせん断帯が広範囲 に分布する傾向を示した。また，補強材長が $1 \mathrm{~m}$ 程度の補強材の設置により変形が抑制され，無補強の場 合と比べて最大せん断ひずみが斜面内部に広がっており，斜面補強効果が確認された.
\end{abstract}

Key Words : soil nailing technique, centrifuge modelling, In-flight excavator, PIV-analysis

\section{1. はじめに}

地山補強土工法は1950年代に欧州において自然地山 の斜面や切土法面に引張り補強材を配置し，斜面や切 土面を安定化する工法として開発された。我が国では 1970年代にトンネルのNATM工法が技術導入されたこ とを契機としてトンネル坑口などの斜面安定化工法と しても採用されるようになった1). その後，切土斜面 の安定化工法として適用が拡大し，現在では掘削土留 め工や既設法面の急勾配化工事，基礎の補強工事など に用途が拡大している．地山補強土工法は，地山内に 補強材を構築し，地山の変形に伴い補強材一受働的に 作用する抵抗力により変形を拘束し地山を安定化させ る工法である．構造的に類似するアンカー工法は主働 的にアンカーロッドにプレストレスを導入する工法で
あることに対して，地山の変形によって受働的に抵抗 力が発生する地山補強土工法は，地山の変形を一定程 度許容する工法とも言える。このような地山補強土工 法は, 地盤工学会の研究委員会1)等を経て, 自然斜面 および切土や盛土の法面などの斜面安定化については 旧 日本道路公団 ${ }^{2)}$ (現 NEXCO) や旧 日本鉄道建 設公団 ${ }^{3)}$ (現 鉄道運輸機構）において基準化が図ら れ, 加えて, 地盤工学会にて「地山補強土設計・施工 マニュアル」が発刊される等の多くの実績を有してい る4)。これら現行の設計法等では，地山と補強材を剛 完全塑性体と仮定しているため, 変形に応じた補強材 の効果を導入することが難しい. しかしながら，基準 等で扱われている地山補強土工法は永久構造物や近接 施工等に利用することが念頭にあり，その変形は十分 小さくする必要があるため, 上記のような扱いでも構 
わないとも言える，一方，斜面崩壊による労働災害の 低減を目的としたハード的な対策方法では, 変形を許 容しつつ崩壊に至らない方法が概念として提示されて いる5)。この概念は地山補強土工法が本来有する機能 である.このような簡易的かつ仮設的な地山補強の崩 壊メカニズムは, 複雑なことが想像され, 実験的研究 による検討が必要である.

本研究は, 斜面崩壊によるリスクが高いと判断さ れた斜面を簡易的かつ仮設的に補強する地山補強につ いて, 掘削過程における斜面安定効果を把握するため の遠心場掘削実験を実施した，本報では，まず，斜面 崩壊による労働災害と災害防止対策について概説し, その後, 地山補強土工法に関する実験的研究の既往研 究のレビューを行った. そして, 新たに開発した遠心 場掘削シミュレーターを用いて地山補強斜面の（1） 斜面勾配，（2）補強材の有無，（3）法面工の有無, を変化させた遠心場掘削実験を実施し, 各種変位計測 およびPIV画像解析等を用いてせん断ひずみ分布や変 形挙動を把握した.

\section{2. 斜面崩壊による労働災害と災害防止対策}

斜面の切取り掘削工事では, 自然斜面の下方部分 を掘削したり，斜面をより急勾配にしたりする場合が 多い.このことは, 地山内部のせん断応力を増加させ たり, 掘削による表面露出や降雨などの外乱要因によ って地山の強度を低下させる結果を招き, 斜面の安定 性を失わせることになりやすい. このような斜面の切 取り掘削工事中に斜面崩壊によって作業員が被災寸る 労働災害は数多く発生している. 伊藤らのの調査・分 析によるとこれらの災害は，（1）崩壊土量が $50 \mathrm{~m}^{3}$ 以 下の小規模崩壊が多く, 退避する時間的余裕も無く被 災する場合が多い，（2）崩壊形態の規模としては表 層崩壊が6割以上を占めている，（3）崩壊形態の地質 としては崩壊土・風化表層土が割弱を占めている, といった特徵が挙げられる. また, 災害の多くが中小 規模工事であり，それらは重力式擁壁やもたれ式擁壁 を築造するための工事に付随して斜面の切土掘削が行 われることが多い，このような場合には，構造物の施 工にかかる作業手順や安全対策については検討されて いるが，斜面崩壞に対する危険性の認識が必ずしも高 くない現状がある，以上のような現状から，（独）労 働安全衛生総合研究所（現（独）労働者健康安全機 構 労㗢安全衛生総合研究所以下, 「安衛研」之言 う）では「斜面崩壊による労働災害の防止対策に関す る調查研究会」（以下，「調查研究会」と言う）を設 置し, 様々な検討を行った ${ }^{5)}$. その中で, 斜面崩壊に よる労働災害を低減することを目的とするハード対策
として，下記の観点・概念による整理を行っている. すなわち,

（1）作業時に作業員が切土部の下部に進入しない又 は短時間の進入ですむ方法,

（2）斜面（残斜面と切土部）を補強する方法（変状 が生じても避難する時間を確保し崩壊土砂が可能 な限り拡散しない方法を含む），

である．調查研究会が示したハード対策の（2）につ いては本来の補強メカニズムの観点からも地山補強土 工法がその概念に合致する工法として位置づけられて いる. しかしながら, 先述したように現行の各種基準 等は永久構造物の施工を主目的としており, 変形を極 力許容しない設計体系である，そのため，これらを準 用することは可能であるが本設使用であるためコスト 的には高価となることから, 変状が生じても粘り強く 崩壞しないような仮設使用を念頭に置いた簡易な地山 補強土工法の検討が必要と考えられる.

\section{3. 地山補強土エ法に関する実験的研究に関す る既往研究}

地山補強土工法に関寸る実験的研究について, 村 松ら》は図-1に示すように，（1）天端からの載荷によ る破壊実験，（2）自重破壊実験（遠心加速度上昇に よる遠心力載荷, 降雨実験等），（3）掘削除荷によ る破壞実験のように3つに分類している。これらのう ち，（1）は載荷重の影響ですべり破壊面が規定され てしまうこと等から実際的ではなく，（2）は施工プ ロセスが考慮されていないため実際と応力とひずみの 状態が異なることを指摘しており, 地山補強土工法の 補強原理を忠実に再現する実験方法としては（3）が 望ましいとしている．このような掘削除荷による地山 補強土工法の破壊実験として, 村松ら》は鉛直面を有 する地山補強土について, あらかじめ配置していた独 立した可動ブロックを水平方向に $0.2 \mathrm{~mm} / \mathrm{min}$ 程度の速 度で段階的に解放することで掘削除荷を再現している。 西村・山本 ${ }^{8)}$ 同様にあらかじめ地山補強を施した銅 粒子による斜面の前面に銅粒子を設置して掘削側の銅 粒子を段階的に排出口から排出させることで掘削除荷 を再現している。一方, 山本ら ${ }^{9}$ は高さ $2.8 \mathrm{~m}$ の模型斜 面にあらかじめ補強材（アンカーボルト）を70度斜面 となる位置に水平に配置して45度斜面を作製し，その 後法肩から 70 度で補強材 1 段毎にボルトで締め付けを 行いながら掘削を行う段階掘削実験を行い, 補強部分 を仮想の擁壁体と考える疑似擁壁理論を構築している. これらの実験的研究は安全上の観点から斜面高さが $2.5 \mathrm{~m}$ 以下で実施されており, 実大規模での破壊メカニ ズムの検討は難しい，掘削除荷による破壊問題は地盤 


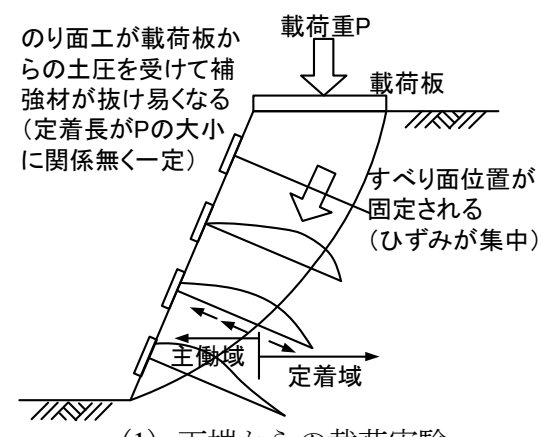

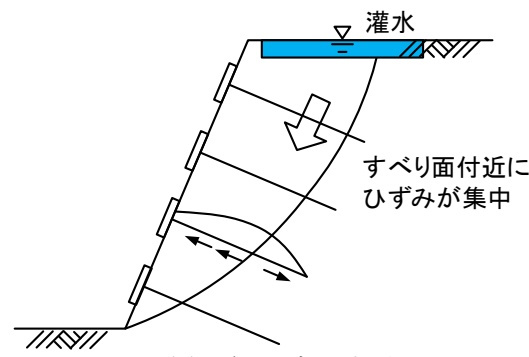

(2) 自重破壊実験

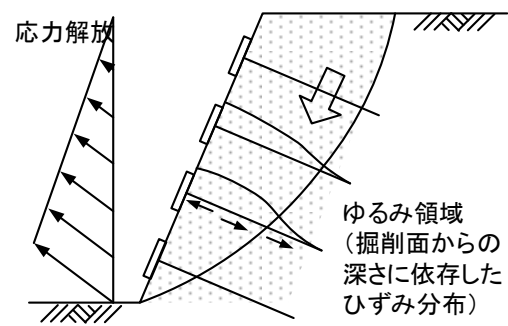

（3）除荷実験

図-1 村松らによる地山補強土工法に関する各種実験方法の分類と問題点（文献 7)の一部改変）

の自重応力が強く関わるため多くのパラメータを変化 させてその影響を把握するためには遠心模型実験を行 うことが合理的である。遠心模型実験において掘削除 荷を再現する方法として大きく2種類の方法がある ${ }^{10}$. すなわち，（1）重液（塩化亜鉛水溶液やヨウ化ナト リウム水溶液）をゴム袋を介して満たしておき，それ を外部に排出する，（2）所定の遠心加速度場にて実 際と同様に掘削を行う。(1)の方法は, 遠心模型実験 の創生期から掘削問題を行う際に利用されてきた手法 であり，地山補強土に適用した事例として，Tei etal. ${ }^{11)}$ やDavis and Jones ${ }^{12)}$ の研究がある． Tei et al. ${ }^{11)}$ は法面の前

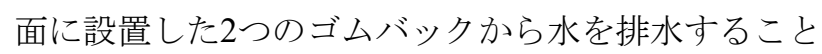
で掘削を再現しており, 崩壊形状は掘削段階に応じて 法尻を起点とする対数らせん状となることを示してい る. Davis and Jones ${ }^{12)}$ は予め地盤内にひずみゲージ付き の補強材を配置した斜面に対してそれに沿った反力壁 に重液（塩化亜鉛水溶液）が入ったゴムバックを設置 し，それを排出することで掘削を再現している. の方法は, 直接的に掘削除荷の再現が可能であるが, 高重力下での掘削制御を行う点で，技術的レベルが高 い. しかしながら1990年代になると, 遠心模型実験に て用いられる種々の載荷装置の開発が行われ，併せて それらの制御技術も急速に発展したことにより, 施工 過程をある程度再現した実験13ト16が行われるようにな った. そして2000年代以降では, 掘削専用システムで はなく汎用性の高い様々なアタッチメントを搭載した 遠心模型実験用ロボットも開発されている17),18).

\section{4. 遠心模型実験の概要}

\section{（1）遠心模型実験装置}

本実験には, 安衛研所有の遠心模型実験装置 (JNIOSH Mark-II Centrifuge，写真-1）を使用した。本 実験装置は, 静的実験と動的実験のプラットホームを 分離・独立させた “非対称ビーム構造” とすることで それぞれの要求性能を満足させ, 実験の効率を高めて いる. 具体的には, 動的実験側には加振実験での実験

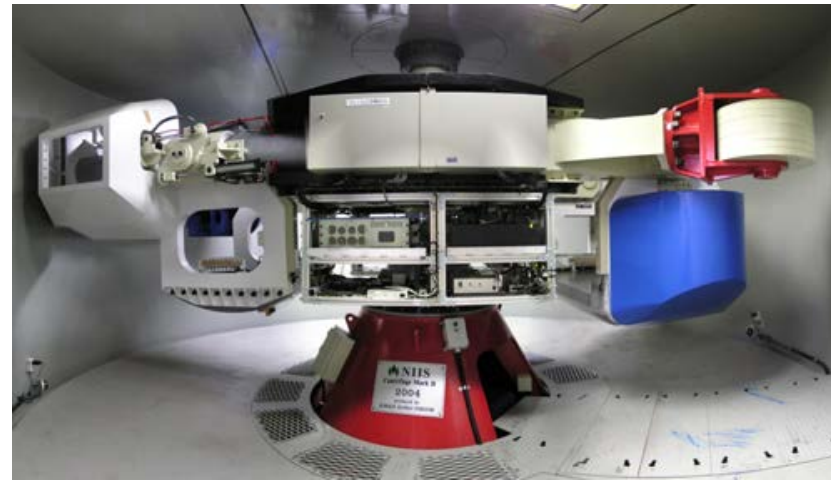

写真-1＼cjkstart遠心模型実験装置 JNIOSH MakrII Centrifuge (労働安全衛生総合研究所所有) $\left.{ }^{19}\right)$

表-1＼cjkstart遠心模型実験装置の主要諸元（静的側）19)

\begin{tabular}{|c|c|c|}
\hline 項目 & \multicolumn{2}{|c|}{ 内容 } \\
\hline $\begin{array}{l}\text { 回転半径 } \\
\end{array}$ & \multicolumn{2}{|c|}{$2.38 \mathrm{~m}$} \\
\hline 最大遠心加速度 & \multicolumn{2}{|c|}{$100 \mathrm{~g}(194 \mathrm{rpm})$} \\
\hline 搭載質量 & \multicolumn{2}{|c|}{$500 \mathrm{~kg}$} \\
\hline 遠心場能力 & \multicolumn{2}{|c|}{50 g-ton } \\
\hline \multirow{2}{*}{ 主電動機 } & 電力容量 & 直流90 kW \\
\hline & 電厓 & $440 \mathrm{~V}$ \\
\hline 減速機 & 潤滑方式 & オイルバス潤滑 \\
\hline
\end{tabular}

精度上バックプレートを設置し, 静的実験側はバック プレートを無くして搭載スペースを広くする形状とし ている．今回使用した静的実験用プラットホームの寸 法は $1300 \mathrm{~mm} \times 1100 \mathrm{~mm}$ であり, 有効半径 $2.2 \mathrm{~m}$ 装置で ありながら, 有効半径 $4 \mathrm{~m}$ 以上の大型装置と同等の搭 載スペースを有している，計測システムは，遠心模型 実験装置内に搭載した計測アンプ（64ch）からのデー タを無線LANにより外部に伝送し, PCにて収録して いる. なお，本遠心模型実験装置の主要諸元（静的実 験用）を表-1に示す. なお, 装置の詳細については文 献 ${ }^{199}$ に詳しい.

\section{（2）遠心場掘削シミュレーター}

本研究では, 地山補強土工法の補強原理を模型レ ベルである程度忠実に再現させるために, 遠心力載荷 


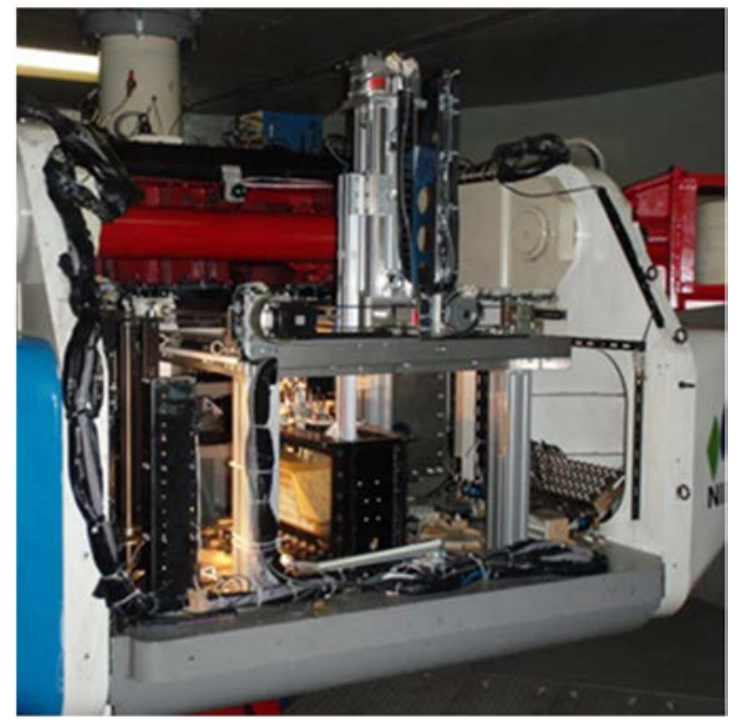

写真-2 遠心場掘削シミュレーター外観

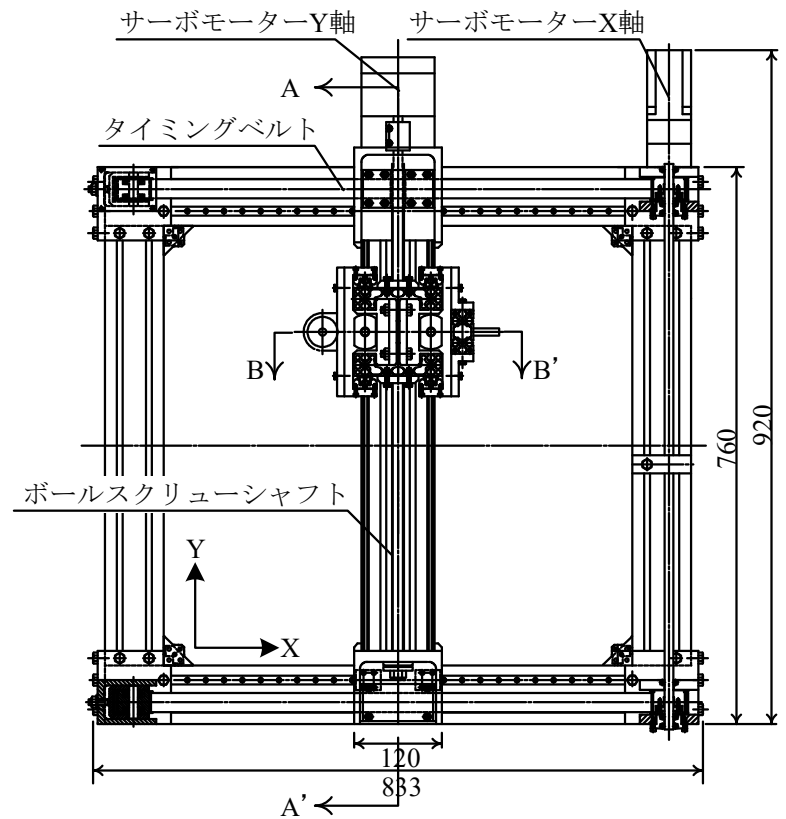

(1) 平面図
表-2 遠心場掘削シミュレーター主要諸元

\begin{tabular}{|c|c|c|}
\hline 軸 & \multicolumn{2}{|c|}{ 各種仕様 } \\
\hline \multirow{3}{*}{$\mathrm{X}$} & \multicolumn{2}{|c|}{ 安川電機製 SGMP-03B314 } \\
\hline & 最大移動速度 $(\mathrm{mm} / \mathrm{s})$ : & 7.50 \\
\hline & 稼働範囲(mm) & 450 \\
\hline \multirow{3}{*}{$Y$} & \multicolumn{2}{|c|}{$\begin{array}{l}\text { ハーモニック・ドライブ・システムズ製 } \\
\text { FHA-14C-100-E200-C }\end{array}$} \\
\hline & 最大移動速度 $(\mathrm{mm} / \mathrm{s})$ ： & 7.50 \\
\hline & 稼働範囲(mm) & 400 \\
\hline \multirow{3}{*}{$\begin{array}{c}\mathrm{Z1} \\
\text { 掘削 }\end{array}$} & \multicolumn{2}{|c|}{\begin{tabular}{|l} 
ハーモニック・ドライブ・システムズ製 \\
FHA-14C-100-E200-C
\end{tabular}} \\
\hline & 最大移動速度 $(\mathrm{mm} / \mathrm{s})$ ： & 3.75 \\
\hline & 稼働範囲(mm) & 300 \\
\hline \multirow{3}{*}{$\begin{array}{c}\mathrm{Z2} \\
\text { 補強・調査 }\end{array}$} & \multicolumn{2}{|c|}{$\begin{array}{l}\text { ハーモニック・ドライブ・システムズ製 } \\
\text { FHA-14C-100-E200-C }\end{array}$} \\
\hline & 最大移動速度 $(\mathrm{mm} / \mathrm{s})$ ： & 3.75 \\
\hline & 稼働範囲(mm) & 300 \\
\hline
\end{tabular}

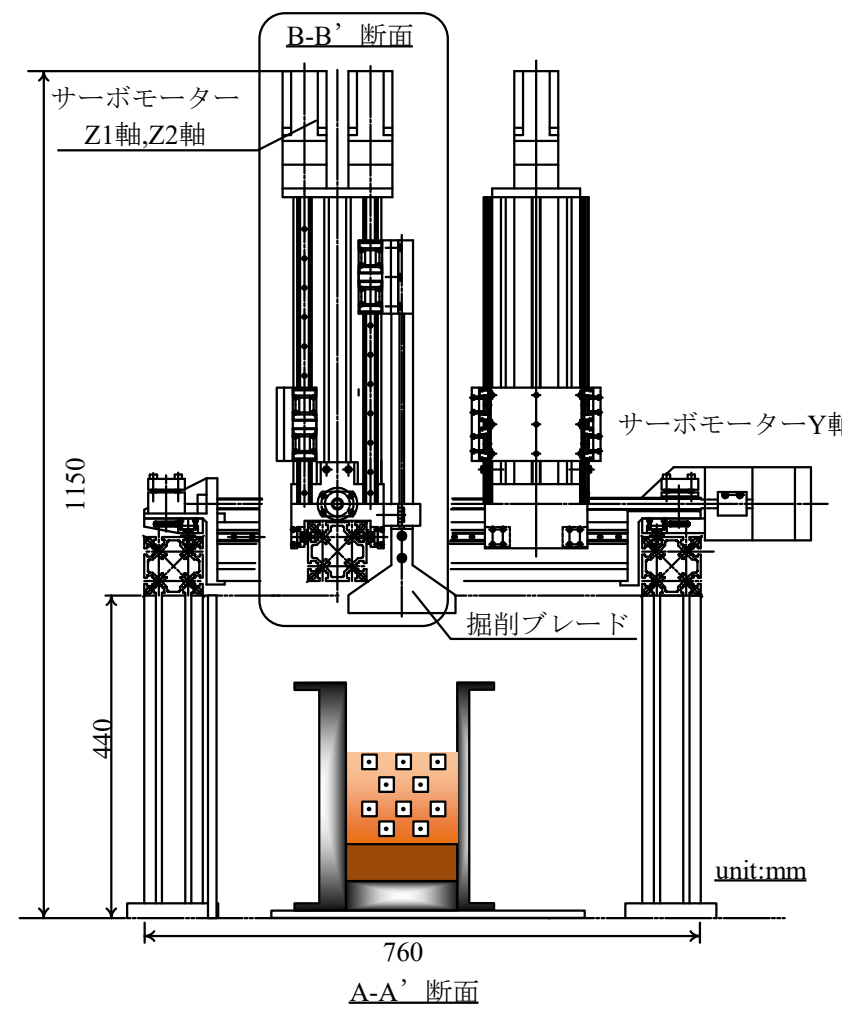

(2) 側面図

図-2＼cjkstart遠心場掘削シミュレーター

時に地盤を掘削することが可能な遠心場掘削シミュレ ーターを使用した．遠心場掘削シミュレーターは2007 年に安衛研に導入され，掘削制御システムの改造等を 経て，本研究にて新たに用いられた装置である。遠心 場掘削シミュレーターの外観を写真-2に, 側面図・平 面図を図-2に，主要諸元を表-2にそれぞれ示す，X軸， Y軸，Z軸の3方向に稼働する点は既往の遠心場掘削装 置 ${ }^{14,15)}$ と同様である. 汎用性の高い遠心模型実験用口 ボット17),18)では様々なアタッチメントを用いて複雑な 動作を行うことができるが, 高重力場での物体の把持
や搬送には困難を伴う。本装置の特徵は，Z軸を2軸 とし，掘削専用軸と補強・調査軸を分離した点にある. これにより斜面を急勾配に掘削した後に補強対策やコ ーン貫入試験を行うように 2 工種程度の別作業を行う ことが可能となる，掘削専用軸は，1度～90度まで1度 刻みでの任意の勾配にて掘削が可能となるようにシス テム化されており，斜面勾配に沿った掘削が可能であ る. 補強・調查軸は任意の載荷速度の設定が可能であ る. なお, 後述するが本研究では, 掘削専用軸のみを 使用している. 
表-3 使用した試料の物理特性

\begin{tabular}{c||c}
\hline & 成田砂 \\
\hline \hline 土粒子密度 $\rho_{\mathrm{s}}\left(\mathrm{g} / \mathrm{cm}^{3}\right)$ & 2.663 \\
\hline 最大粒径 $(\mathrm{mm})$ & 2 \\
\hline $60 \%$ 粒径 $D_{60}(\mathrm{~mm})$ & 0.2238 \\
\hline $50 \%$ 粒径 $D_{50}(\mathrm{~mm})$ & 0.1909 \\
\hline $30 \%$ 粒径 $D_{30}(\mathrm{~mm})$ & 0.1310 \\
\hline $10 \%$ 粒径 $D_{10}(\mathrm{~mm})$ & 0.0055 \\
\hline 均等係数 $U_{\mathrm{C}}$ & 40.7 \\
曲率係数 $U_{\mathrm{C}}$ & 13.9 \\
\hline 地盤材料の分類名 & 細粒分砂 \\
\hline 最適含水比 $w_{\mathrm{opt}}(\%)$ & 17.2 \\
\hline 最大乾燥密度 $\rho_{\mathrm{dmax}}\left(\mathrm{g} / \mathrm{cm}^{3}\right)$ & 1.77 \\
\hline
\end{tabular}

(3) モデル化について

a) 地山補強斜面のモデル化

使用した実験土槽は，幅 $450 \mathrm{~mm} \times$ 高さ $270 \mathrm{~mm} \times$ 奥 行き $150 \mathrm{~mm}$ のアルミ製土槽であり，土槽の片側側面 は強化ガラス面により内部の様子を観察できる．模型 地盤は, 法面高さ $5 \mathrm{~m}$ の斜面を $1 / 40$ 縮尺モデルとして 作製した．試料は，最大粒径が $2.0 \mathrm{~mm}$ となるように粒 度調整した成田砂である。成田砂の物理特性を表-3に, 締固め曲線を図-3にそれぞれ示す。

地山補強土工法は, 水平方向に補強材が配置され る盛土補強土工法とは異なり，任意角度にて打設され ることが多い。このような地山補強土工法の補強材設 置をモデル化するために，本研究では模型斜面を側方 方向から作製した．載荷方向が異なることにより強度 や変形の異方性が見られることは, Oda et al.らの研究 等によって明らかにされている ${ }^{20)}$. 本研究では，同一 地盤を用いて補強材配置の有無や配置間隔の違いが崩 壊挙動に与える影響を把握することを目的としており， 強度・変形の異方性については大きな問題にならない と判断した．なお，このように模型斜面を側方方向か ら作製する方法は，斜面の植生（根系）による安定性 について検討した Sonnenberg et al. ${ }^{21)}$ や $\mathrm{Ng}$ et al. ${ }^{22)}$ によっ てもされている．地山補強土を配置した場合の地盤作 製フローを図-4に示す．まず，模型土槽を横に倒し， 実験ケースの斜面勾配となる型枠を設置する（図4(1)）. 次に型枠内に所定量の試料を投入し, ベロフ ラムシリンダーにより圧縮して地盤を作製する（図$4(2) ）$. 本実験では，最適含水比 $w=17.2 （ \%)$ に調整 した試料を湿潤単位体積重量 $\gamma_{\mathrm{t}}=15.48\left(\mathrm{kN} / \mathrm{m}^{2}\right)$ とな るように必要量を投入しており, 地盤の締固め度は $\left.D_{\mathrm{c}}=76 （ \%\right)$ となる，その後，なじむように地盤表面 を羁書いた後, 所定の箇所に補強材を斜面と直交方向

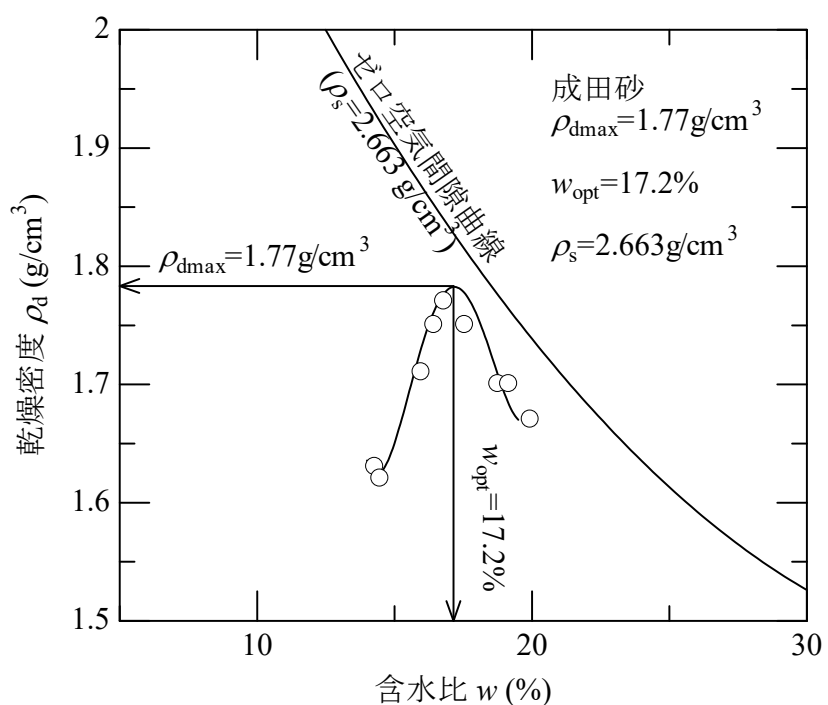

図-3 成田砂の締固め曲線

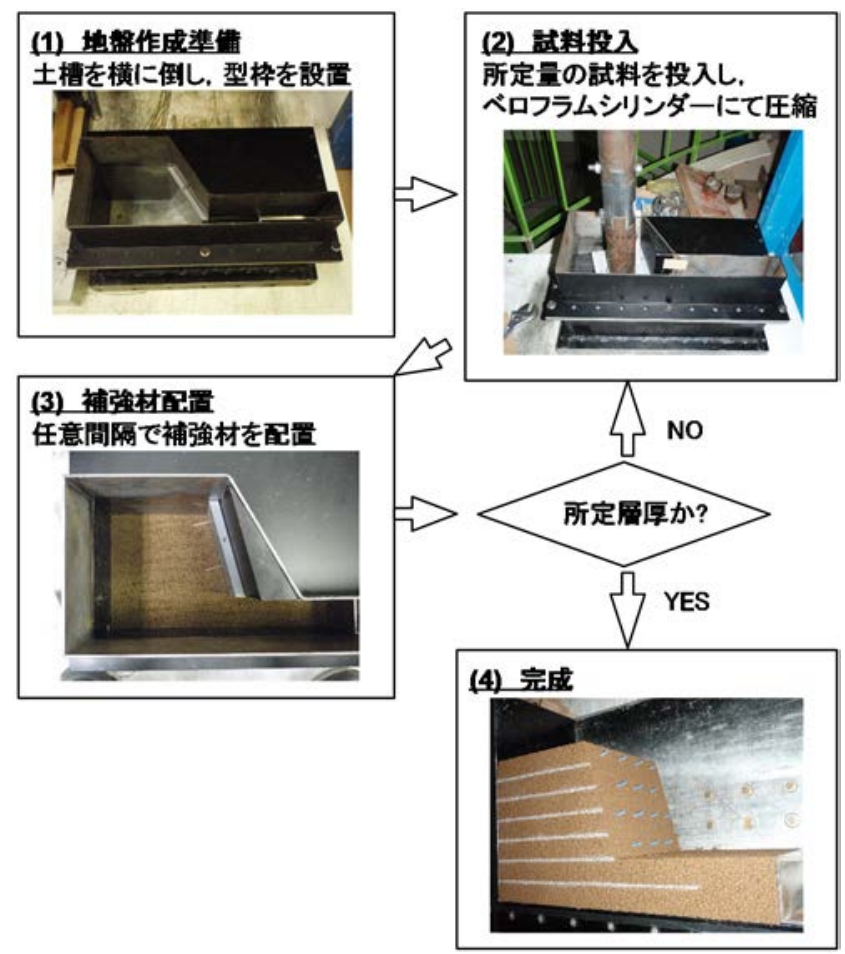

図-4 模型地盤作成方法

に配置する（図-4(3)）。その後, 再び試料を投入し て地盤を作製する．最終的に完成した地盤（図-4(4)） に潤滑スプレーを塗布した強化ガラス側板を取り付け た.

b) 補強材 · 表面材のモデル化

地山補強土工法に使用寸る補強材について, 舘山 は補強材径を主なパラメータとしてネイリング，マイ クロパイリング，ダウアリングの 3 種類に分類して整 理している ${ }^{23)}$ ，それによると，それぞれの補強材径は， ネイリングが $10 \mathrm{~cm}$ 程度以下, マイクロパイリングが 10〜20cm，ダウアリングが $30 〜 50 \mathrm{~cm}$ と分類されてい る. 本研究で使用した模型補強材は, $\phi 3.0 \mathrm{~mm} の \mathrm{MC}$ 
ナイロン（MC901，引張弾性率 3432MPa，曲げ弾性率 $3530 \mathrm{MPa})$ であり，40 倍とした実地盤換算では $\phi 12 \mathrm{~cm}$ となるため, 補強材径からはマイクロパイリングに分 類される．模型補強材の周囲には成田砂を接着して完 全粗の状態とした（図-5(1)）。また, 補強材間隔は, 経験的手法 ${ }^{2}$ から “ $2 \mathrm{~m}^{2}$ に1本”とした「密」(図-5(2)) と，それよりも間隔を広げ “最大 $4 \mathrm{~m}^{2}$ に 1 本” とした 「疎」（図-5(3)）の2 種類について実施した.

地山補強土工法に使用する表面材については, 補 強材との相互作用によって地山を拘束する効果が期待 されており，機能や役割に応じて壁面工，支圧板，法 面保護材の 3 つに大別されている ${ }^{4)}$. 本研究では, 仮 設使用であることを念頭に $25 \mathrm{~mm} \times 25 \mathrm{~mm} \times 2 \mathrm{~mm}$ のプ ラスチック板を支圧板として使用し，補強材間隔が

「疎」の斜面のみに配置した（図-5(4)）。なお，補 強材頭部は M3 のネジ切り加工を施しており, 支圧板 設置後にプラスチック製 M3 ボルトで締めている.

\section{（4）実験方法と実験ケース}

図-6 に模型地盤（斜面勾配 75 度）の概略図を示す. 掘削除荷過程は, 斜面前面側にあらかじめ設置した乾 燥砂（カウンターウエイト）を遠心場掘削シミュレー ターの掘削ブレードによって段階的に除去することで これを簡易的に再現した（図-6）。本来，地山補強土 工法のプロセスを忠実に再現するためには，斜面を所 定高さで掘削した後に補強材を削孔/打設により設置 することが必要である．遠心場掘削シミュレーターは このようなプロセスを再現できるように Z 軸を 2 軸と しているが，遠心場での補強材の把持・打設プロセス には技術的課題が残されていることから，本研究では
山本ら 9)が実施したように補強材を既に斜面内に打設 した状態での斜面を遠心場にて遠心場掘削シミュレー ターによって掘削することで地山補強土工法の施工を 再現している. 掘削した乾燥砂（カウンターウエイト） は，斜面崩壊に影響を与えない箇所に配置した排土ボ ックス（図-6）に排土している.1 回の掘削高さは $12.5 \mathrm{~mm}$ （実地盤換算で $0.5 \mathrm{~m}$ ）とし，掘削が完了した 段階で約 2 分間放置した。 これを斜面高さ $200 \mathrm{~mm}$ （実 地盤換算で $5.0 \mathrm{~m}$ ） となるまで段階的に掘削を行った. なお，後述する水平変位や鉛直変位に変化が見られる 場合は, その挙動が安定状態となるまで放置時間を延 長して観察した. 計測項目は, 法面天端の図-6に示寸

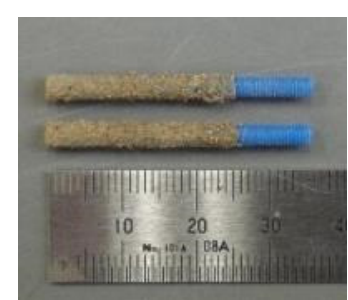

(1) 模型補強材

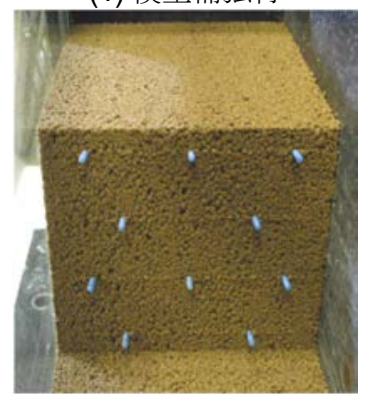

(3) 最大 $4 m^{2}$ に 1 本「踈」
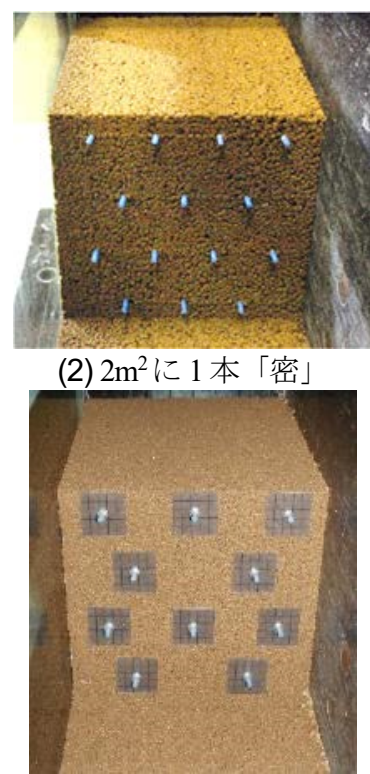

(4) 支圧板
図-5 補強材・表面材の配置

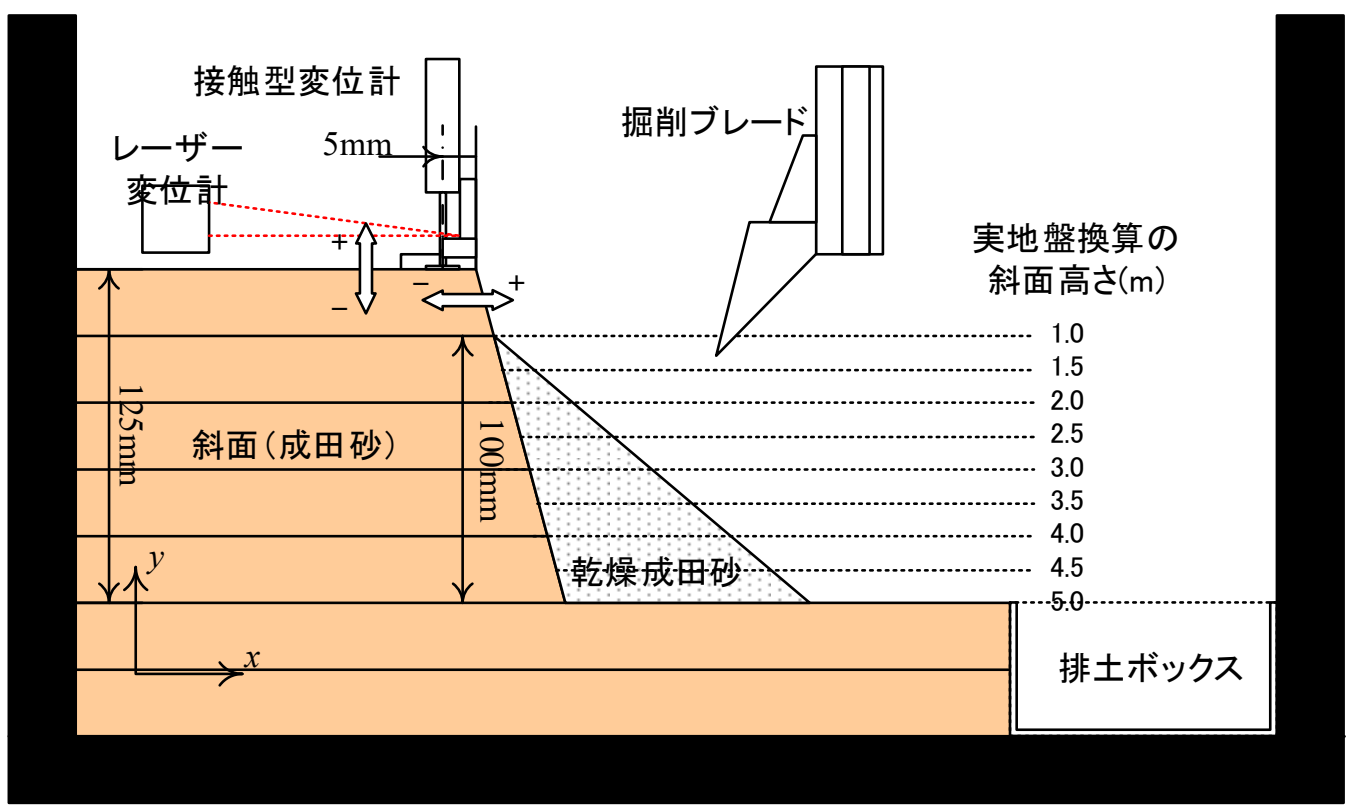

図-6 模型寸法および計測器等配置図 
表-4 実験ケース

\begin{tabular}{|c|c|c|c|c|}
\hline \multirow{2}{*}{ ケース } & \multirow{2}{*}{ 勾配 } & \multicolumn{2}{|c|}{ 補強材 } & \multirow{2}{*}{ 表面材 } \\
\hline & & 補強材長 & 配置 & \\
\hline 1 & \multirow{2}{*}{60 度 } & - & & \multirow{5}{*}{ - } \\
\hline 2 & & $1 \mathrm{~m}$ & 密 & \\
\hline 3 & \multirow{4}{*}{75 度 } & - & & \\
\hline 4 & & \multirow{3}{*}{$1 \mathrm{~m}$} & 密 & \\
\hline 5 & & & \multirow{2}{*}{ 疎 } & \\
\hline 6 & & & & 支圧板 \\
\hline
\end{tabular}

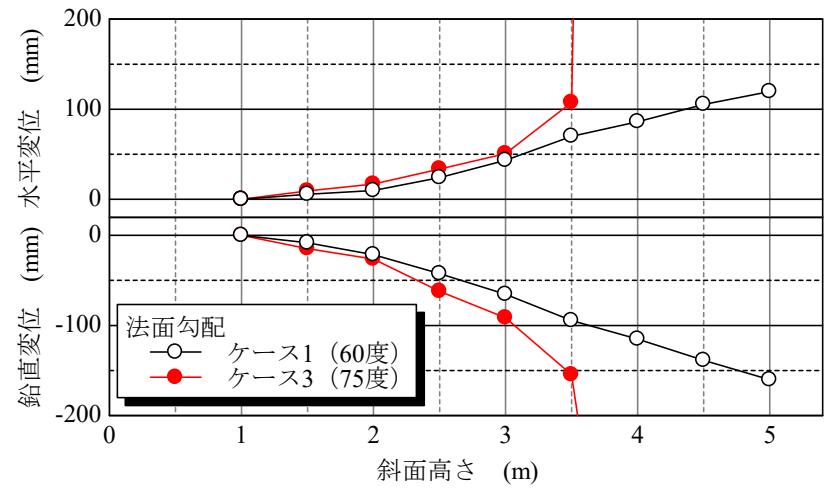

図-7 無補強地盤の各段階の鉛直・水平変位

法肩から $5 \mathrm{~mm}$ の位置に設置した接触型変位計による 鉛直変位と法肩から $0 \mathrm{~mm}$ の位置に設置したレーザー 変位計による法面天端の水平変位である。また，土槽 正面には，観察用の CCD カメラ（30 万画素）ととも に PIV 画像解析用の高解像度カメラ（東芝 TELI 製 CS6931E，2048×1536pixel，20 秒/コマ）を設置して掘 削過程の地盤変形を撮影している。地盤変形は粒子画 像流速測定法（Particle Image Velocimetory，以下「PIV」 という）24)25)により計測した。 高解像度カメラで撮影 した画像はカメラレンズの歪みが生じるため, 画像の 幾何補正によってその歪みを補正した。 また，PIVの 直接相互相関法 26)を用いて，2つの画像間の変位量を 求め, さらにそれらの変位量をラプラス方程式再配置 法 26)を用いて掘削初期からの地盤の連続した変位（ひ ずみ）を求めた。なお，本研究の画角と画素数から PIV 画像解析の変位精度は $0.168 \mathrm{~mm}$ である.

実験ケースを表-4に示す。斜面勾配の違いと補強材 や法面工の有無に着目して計 6 ケースの実験を行った. 以下，実験結果は全て実地盤換算にて表記する.

\section{5. 遠心模型実験の結果と考察}

\section{（1）斜面勾配の違い}

図-7に斜面勾配が異なる 2 種類の無補強地盤の掘削 段階毎における法面天端の水平変位と鉛直変位をそれ ぞれ示す。両ケースとも掘削が進むにつれて水平，鉛 直ともに変位量が大きくなり，ケース 3 （75 度斜面）
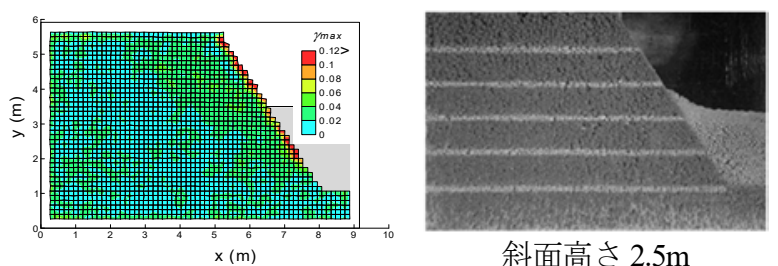

斜面高さ $2.5 \mathrm{~m}$
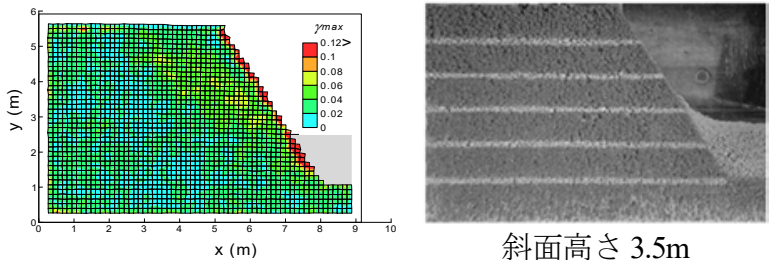

斜面高さ $3.5 \mathrm{~m}$
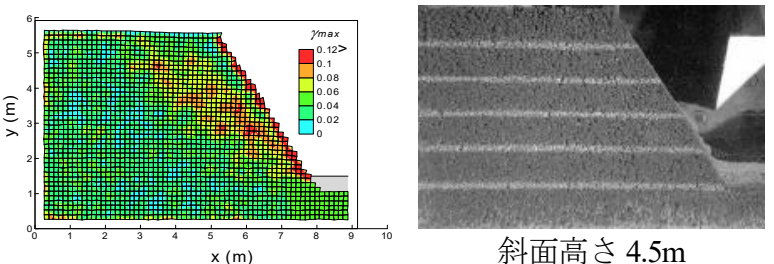

斜面高さ $4.5 \mathrm{~m}$
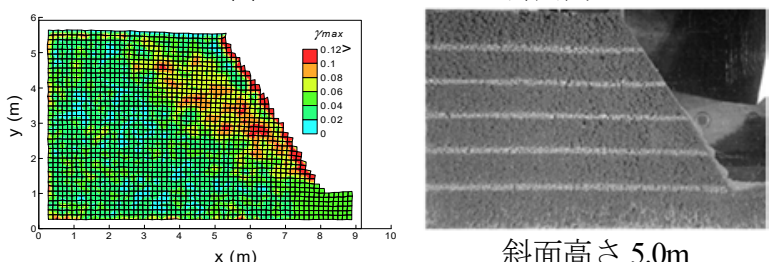

斜面高さ $5.0 \mathrm{~m}$
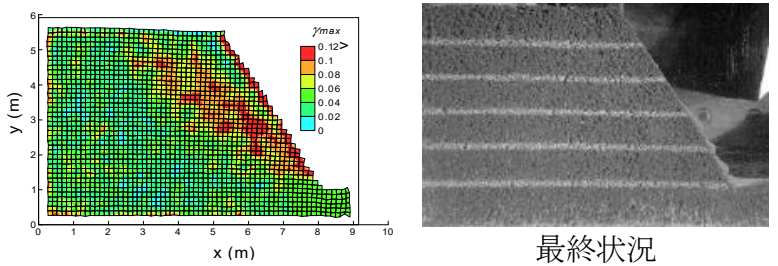

最終状況

図-8 PIV 画像解析による変形図（等倍）と最大せん断 ひずみ分布（左）の推移およびその写真（右） (ケース 1,60 度斜面)

では斜面高さ $3.5 \mathrm{~m}$ まで掘削した際に崩壊した。一方， ケース 1（60 度斜面）では斜面高さ $5.0 \mathrm{~m}$ となっても 崩壊に至らなかった。図-8 はケース 1（60 度斜面）に おける PIV 画像解析から得られた変形挙動（等倍）と 最大せん断ひずみ分布の推移である. なお，各段階で の斜面高さが分かるように床面を死色ハッチで示して いる.これをみると, 各掘削段階の法尻付近から最大 せん断ひずみが卓越し，ひずみ領域が天端に向かって 広がっていることが確認できる．図-9 はケース 3（75 度斜面）における PIV 画像解析から得られた変形挙動

（等倍）と最大せん断ひずみ分布の推移である. 最大 せん断ひずみの発現はケース 1 と同様の傾向を示して いる.しかし，各掘削段階による最大せん断ひずみの 変化は，斜面勾配が急勾配であるケース 3 のほうが大 きい. 例えば，斜面高さ $3.0 \mathrm{~m}$ では法尻部に $\gamma_{\max }=0.1$ 以 上（赤色）はほとんど見られていないが，斜面高さ $3.5 \mathrm{~m}$ では $\gamma_{\max }=0.1$ 以上（赤色）は法尻部から天端に向 

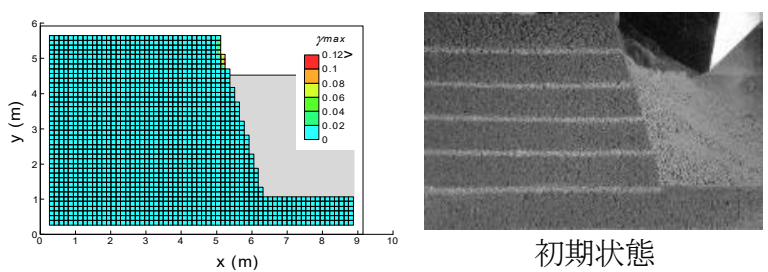

初期状態
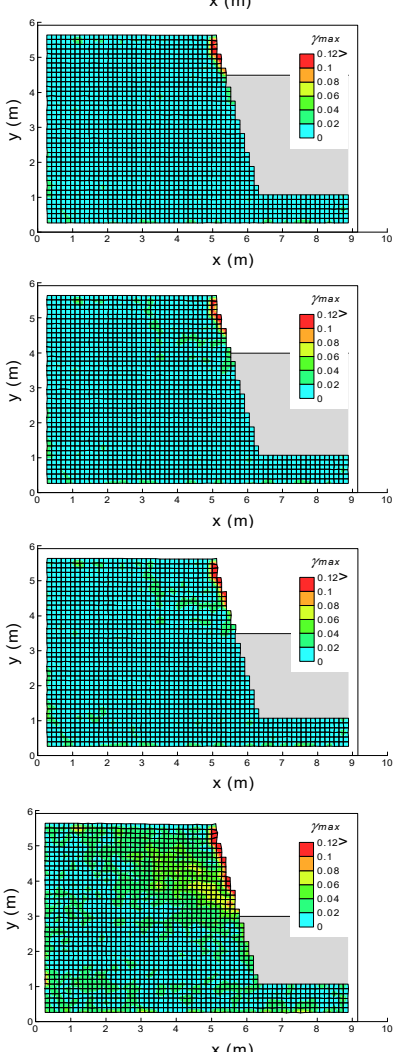

$\mathrm{x}(\mathrm{m})$

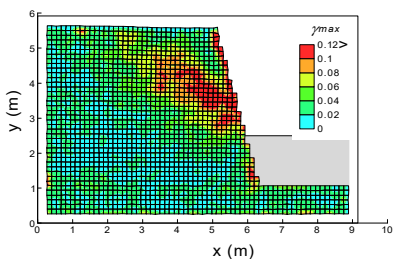

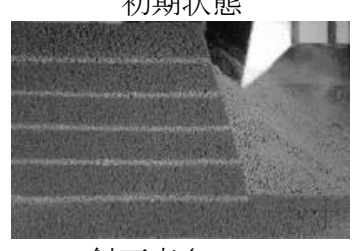

斜面高さ $1.5 \mathrm{~m}$

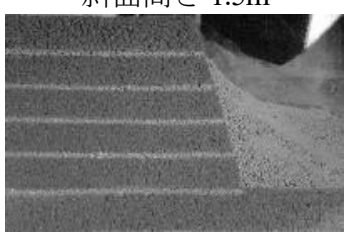

斜面高さ $2.0 \mathrm{~m}$

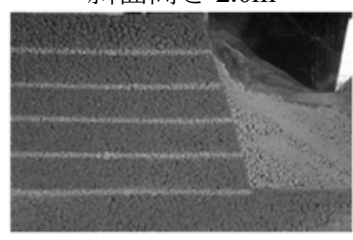

斜面高さ $2.5 \mathrm{~m}$

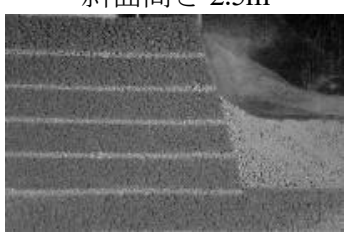

斜面高さ $3.0 \mathrm{~m}$

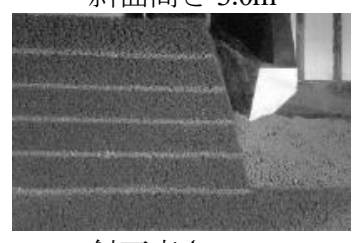

斜面高さ $3.5 \mathrm{~m}$

図-9 PIV 画像解析による変形図（等倍）と最大せん断 ひずみ分布（左）の推移およびその写真（右） (ケース 3,75 度斜面)

かって広がっている. どちらのケースにおいても段階 的に斜面上部から切土掘削作業を行うため, せん断ひ ずみが卓越する法尻部の位置が段階的に斜面下方に移 動する，そのため，法尻部へのせん断ひずみの集中を

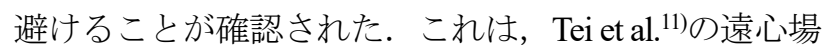
掘削実験での結果や田山ら ${ }^{27}$ の実大規模実験の結果と も合致するものである.

\section{（2）補強材の有無による斜面補強効果}

図-10，11 に斜面勾配毎の各掘削段階における法面 天端の水平変位と鉛直変位をそれぞれ示寸. 補強材設 置による変形抑制効果は, 斜面高さ $2.0 \mathrm{~m}$ 付近までの 掘削初期段階ではあまり見られない. 一方, 斜面高さ $2.5 \mathrm{~m}$ 以上では補強材設置による変形抑制効果が表れ

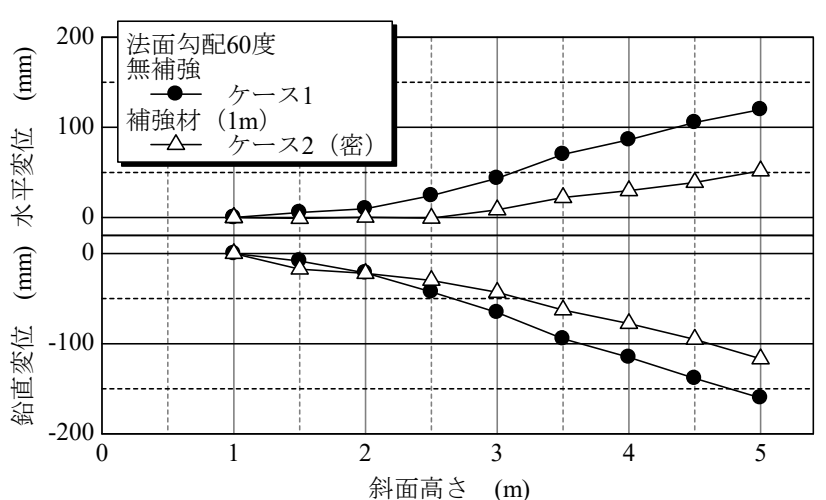

図-10 補強材有無の違い（60 度斜面）の各段階の鉛直・水 平变位
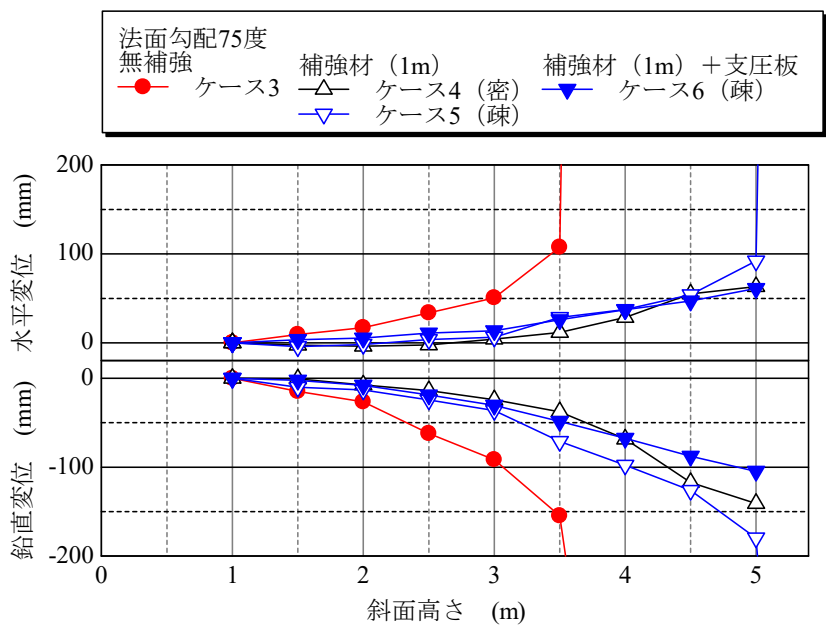

図-11 補強材・表面材有無の違い（75 度斜面）の各段階の 鉛直・水平変位

ている。これは，地山補強土工法が地山の変形によっ て補強材一受動的に抵抗力を発生させて地山を拘束す る補強メカニズムである特徴を捉えている。ここで, 75 度斜面の補強材間隔の違いについて, PIV 画像解析 から得られた変形挙動（等倍）と最大せん断ひずみ分 布の推移を図-12, 13 に示寸.これらの図には補強材 の配置位置 (白線) も追加して示している. 両ケース とも無補強地盤であるケース 3 (図-9）と比較して補 強材設置により最大せん断ひずみが斜面内部に広がっ ていることが分かる。このことから補強材長 $1 \mathrm{~m}$ 程度 の補強材設置でも斜面補強効果がある事が確認された. なお, 補強材間隔の違いは, 斜面高さ $5.0 \mathrm{~m}$ 掘削後に 発現した．写真-3 はケース 5 (補強材間隔（疎））で の最終崩壊に至るまでの CCD カメラの動画を抽出し たものである. ケース 5 では初めに補強材と補強材の 間の斜面を起点として中抜けするような小崩壊が発生 した（写真-3(2)赤丸付近）。その後, 補強材下部も 含めた法尻部全体が小崩壊（写真-3(3)赤丸付近）し た直後に, 進行的に全体崩壊（写真-3(4)）に至って いる。 ケース 4 とケース 5 から補強材間隔は，中抜け 

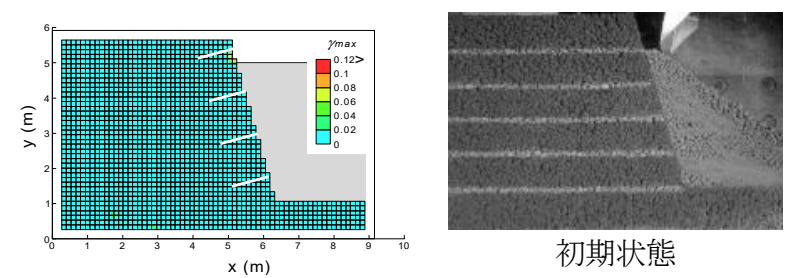

初期状態
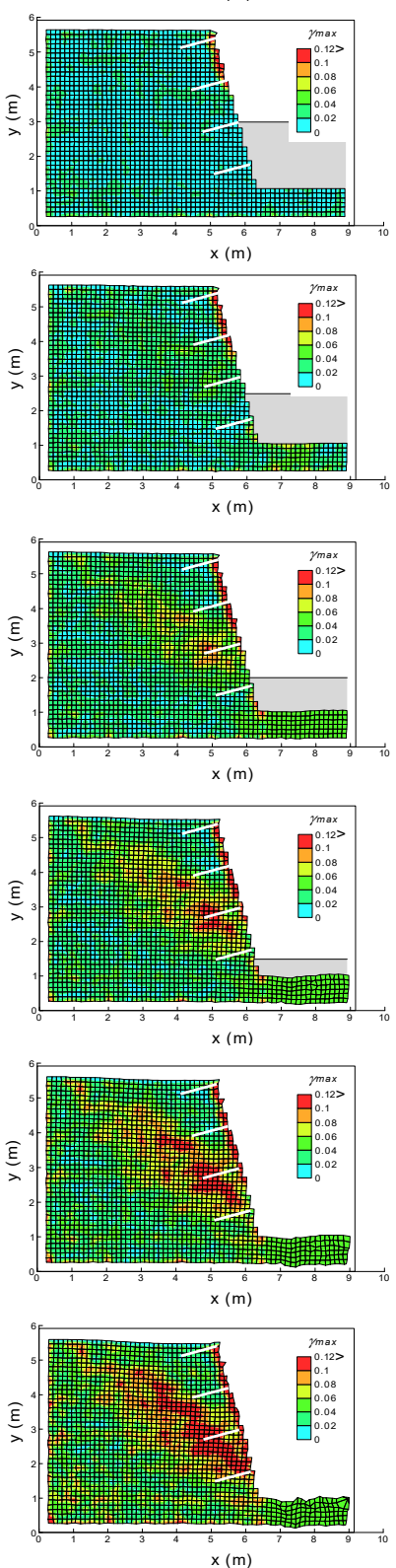

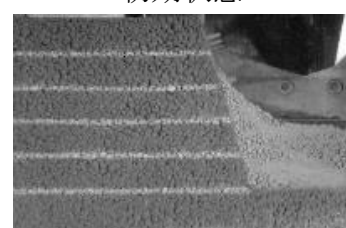

斜面高さ $3.0 \mathrm{~m}$

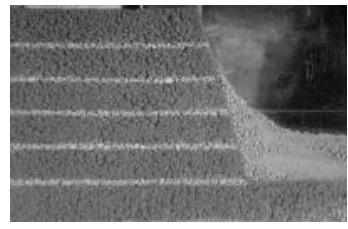

斜面高さ $3.5 \mathrm{~m}$

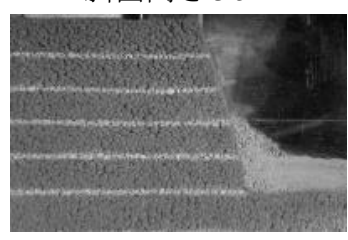

斜面高さ $4.0 \mathrm{~m}$

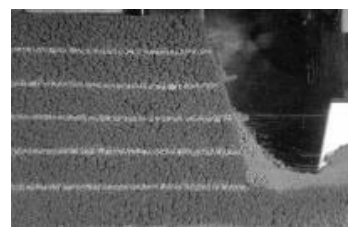

斜面高さ $4.5 \mathrm{~m}$

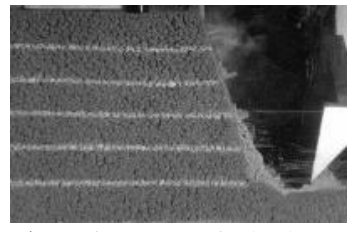

斜面高さ $5.0 \mathrm{~m}$ 掘削直後

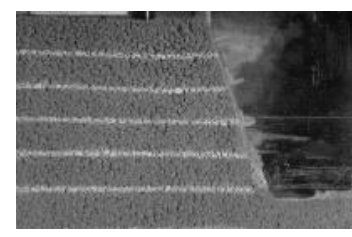

実験終了直前

図-12 PIV 画像解析による変形図（等倍）と最大せん断ひ ずみ分布（左）の推移およびその写真（右）（ケー ス 4,75 度斜面・密 $)$

しない程度の補強材間隔を選択する事が斜面安定上重 要であると言える.

\section{（3）表面材の有無による斜面補強効果}

図-11に 75 度斜面にて実施した全てのケースの掘削 段階毎における法面天端の水平変位と鉛直変位をそれ ぞれ示寸．補強材間隔が同じ条件（疎）でも表面材の 有無によって掘削最終段階での挙動に違いがみられて
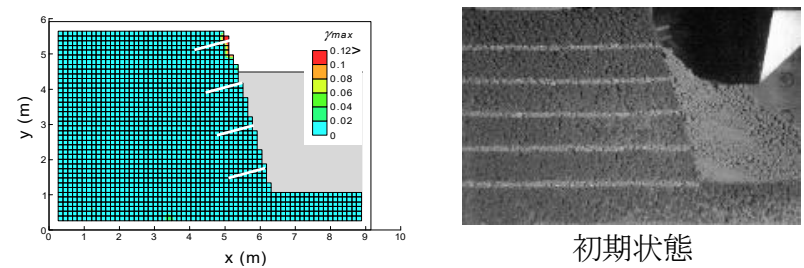

初期状態
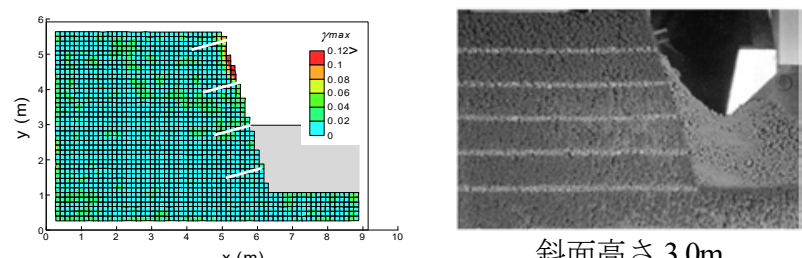

斜面高さ $3.0 \mathrm{~m}$
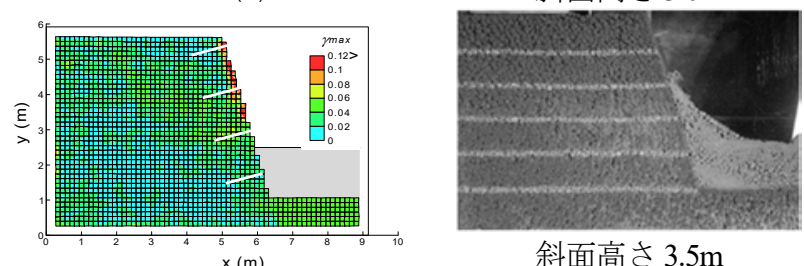

斜面高さ $3.5 \mathrm{~m}$
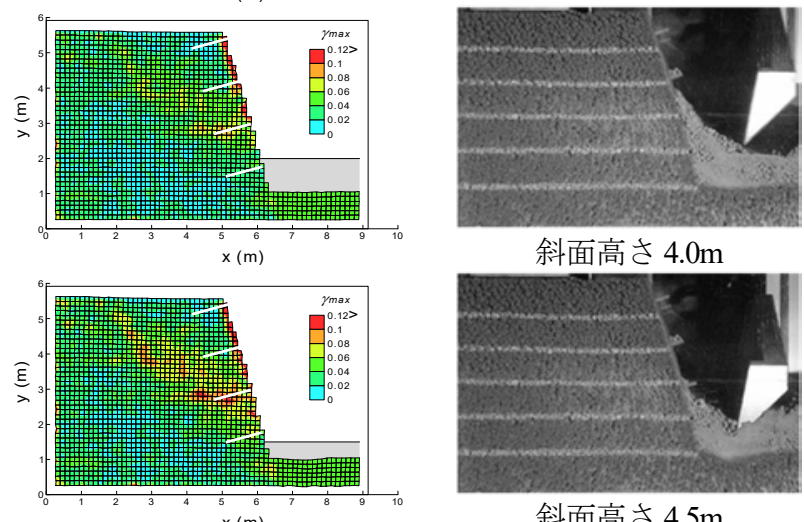

斜面高さ $4.0 \mathrm{~m}$

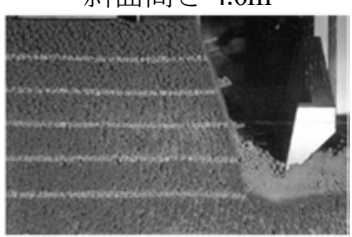

斜面高さ $4.5 \mathrm{~m}$
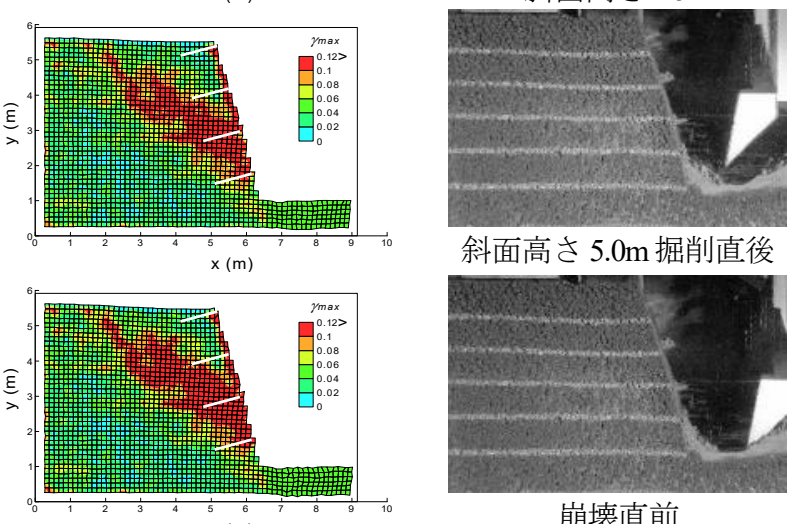

斜面高さ $5.0 \mathrm{~m}$ 掘削直後

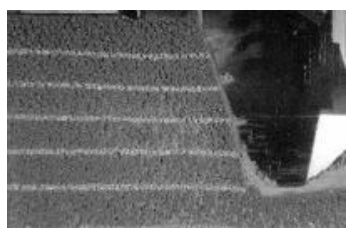

崩壊直前

図-13 PIV 画像解析による変形図（等倍）と最大せん断ひ ずみ分布（左）の推移およびその写真（右）（ケー ス 5, 75 度斜面・疎)

いる．すなわち，表面材が無いケース 5 では斜面高さ $5.0 \mathrm{~m}$ まで掘削すると崩壊に至るが, 表面材があるケ 一ス 6 は崩壊には至っていない，特に，鉛直変位では 掘削が進行して斜面高さが高くなると同様に崩壊に至 らなかったケース 4（補強材間隔（密））よりも変位 の抑制が確認された. 図-14 は表面材があるケース 6 のPIV 画像解析から得られた変形挙動（等倍）と最大 せん断ひずみ分布の推移である. 同様に崩壊に至らな 


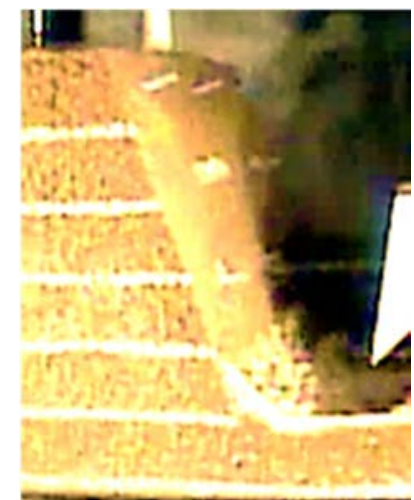

(1) 掘削直後

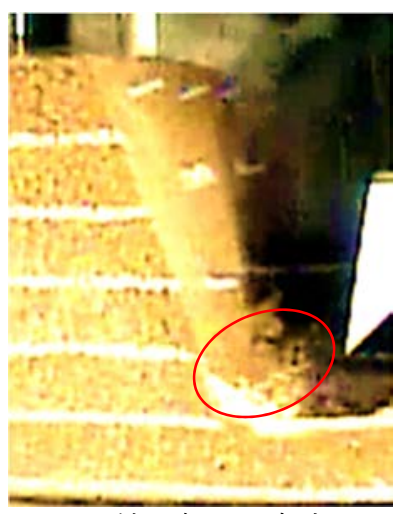

(3) 法尻部の小崩壊

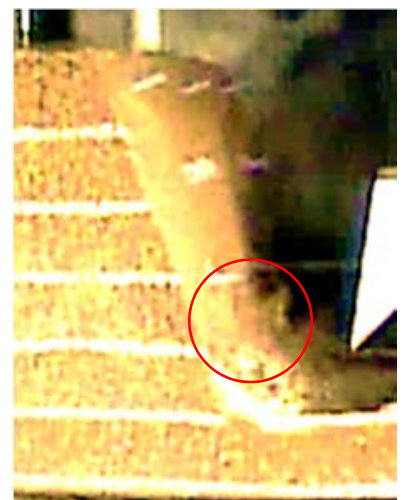

(2) 補強材間の中抜け崩壊

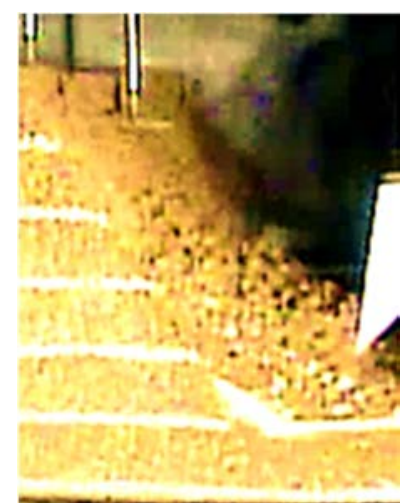

(4) 最終的な崩壊
写真-3 ケース 5 （75 度斜面・疎）での崩壊直前の補強材間 の中抜け挙動（動画キャプチャー）

かったケース 4（補強材間隔（密））と比較しても最 大せん断ひずみ量は抑制されており，鉛直変位の抑制 も含めて表面材による支圧抵抗力が発揮されたことが 示唆される.

\section{6. まとめ}

斜面崩壊によるリスクが高いと判断された斜面を簡 易的・仮設的に補強する斜面補強工法について，掘削 除荷過程における斜面安定効果を把握するための遠心 場掘削実験を実施した。本研究にて得られた知見は以 下の通りである.

無補強地盤の掘削実験より，

1. PIV による画像解析結果から, 段階的に切土掘削 作業を行うことによりせん断ひずみが卓越する 法尻部の位置が変化するため, せん断ひずみが 集中せずにせん断帯が広範囲に分布する事を確 認した.

補強材・表面材設置地盤の掘削実験結果より,

2. 補強材の設置による変形抑制効果は，掘削初期 段階ではあまり発現せず，一定程度の変形に伴 って補強効果が発揮されることが確認された.

3. 補強材を設置によって最大せん断ひずみが斜面
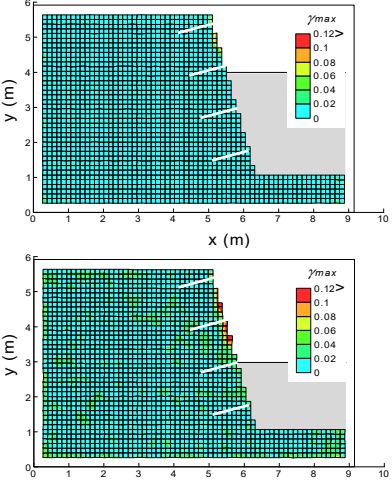

$x(m)$
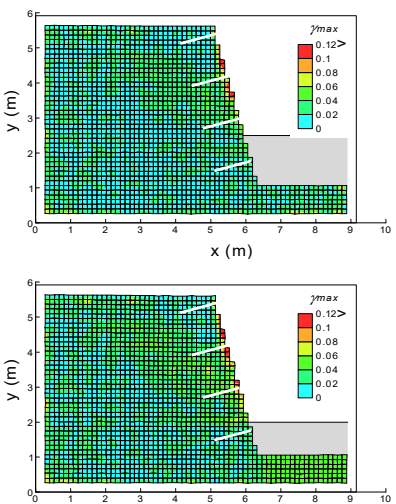

$x(m)$
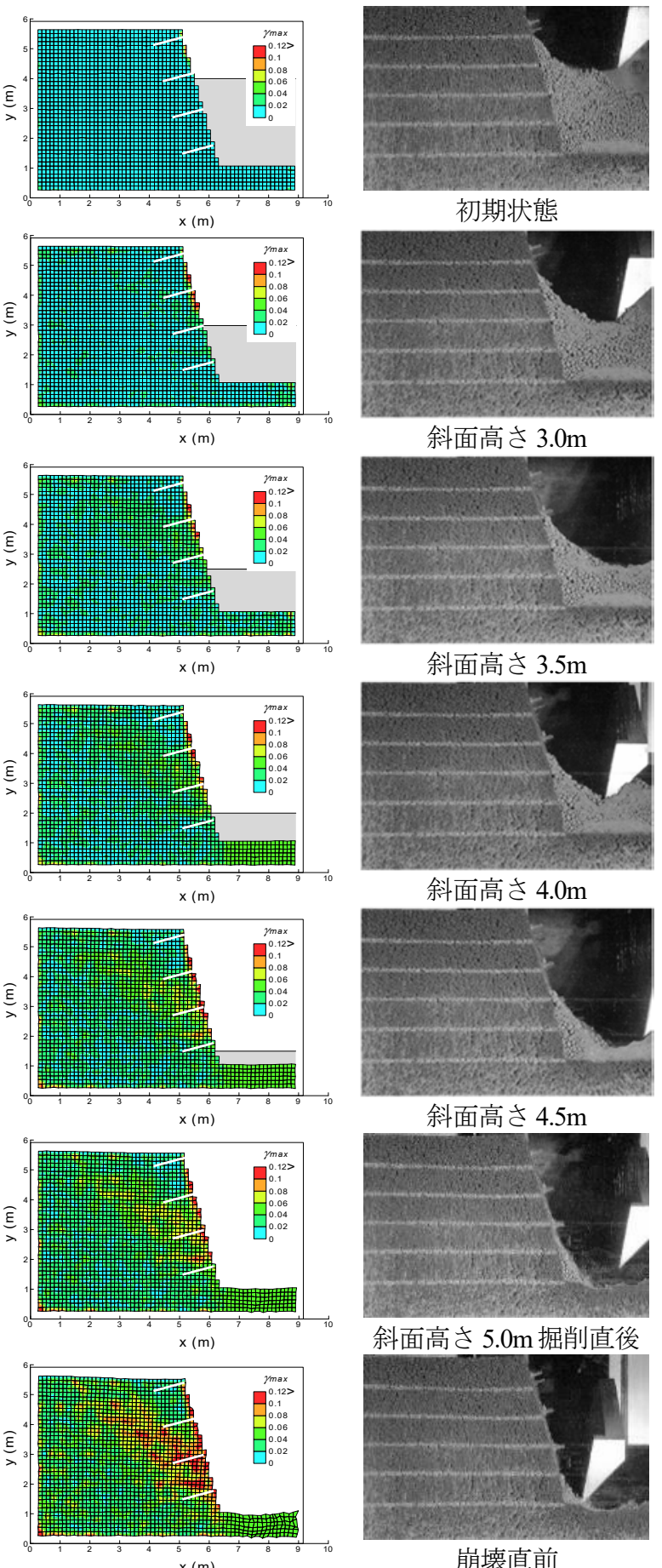

初期状態

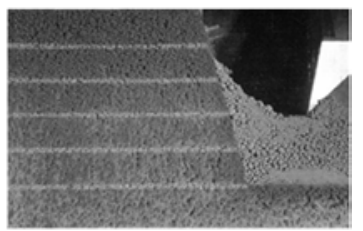

斜面高さ $3.0 \mathrm{~m}$

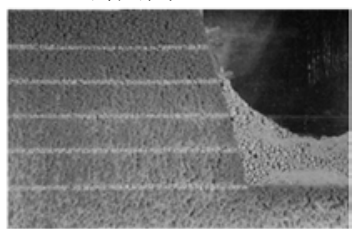

斜面高さ $3.5 \mathrm{~m}$

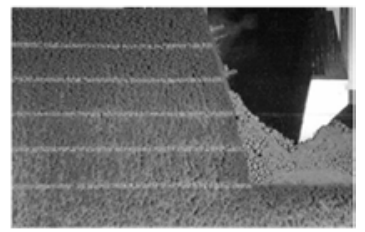

斜面高さ $4.0 \mathrm{~m}$

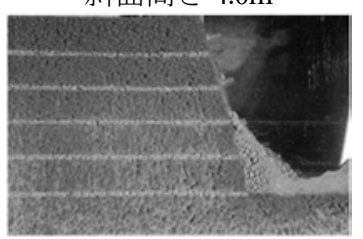

斜面高さ $4.5 \mathrm{~m}$

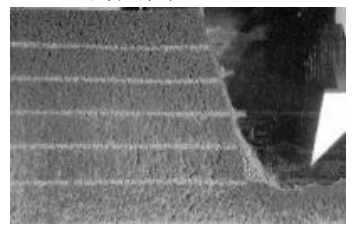

斜面高さ $5.0 \mathrm{~m}$ 掘削直後

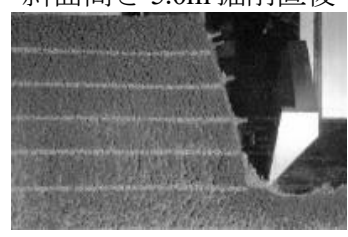

崩壊直前

図-14 PIV 画像解析による変形図（等倍）と最大せん断 ひずみ分布（左）の推移およびその写真（右） (ケース 6,75 度斜面・疎・支圧版)

内部に広がっており, 補強材長 $1 \mathrm{~m}$ 程度の補強材 設置でも斜面補強効果があることを確認した。

4. 補強材間隔を最大 $4 \mathrm{~m}^{2}$ に 1 本と通常よりも疎の状 態とすると補強材と補強材の間から中抜けによ る小崩壊が発生し, その後進行的な全体崩壊に 至っている，そのため，中抜けしない程度の補 強材間隔の選定が斜面安定上重要である. 
5. 表面材として支圧板を設置した場合，支圧抵抗 力の発現によって密に補強材を配置した場合と 比較しても最大せん断ひずみ量や鉛直変位は抑 制されていた.

今回の実験は, 補強材や表面材の材料パラメータ が実際とは異なるため, より実際に近い状態でも今後 検討したい.

謝辞 : 遠心模型実験の実施に際しては, ジオデザイン （株）丸山憲治氏（現 前田建設工業（株））に多大 なるご協力を頂いた．ここに記して深甚の謝意を表し ます．また，本論文を查読して頂いた查読者の方々に は，多くの建設的な御指摘および御意見を頂戴いたし ました。ここに記して深く感謝致します。

\section{参考文献}

1）地盤工学会：地山補強土工法に関する研究委員会報 告, 地山補強土工法に関するシンポジウム論文集, pp. 17-27, 1996.

2) 東日本 - 中日本 $\cdot$ 西日本高速道路: 切土補強土工法 設計・施工要領, 2007 .

3) 日本鉄道建設公団 : 補強土留壁設計・施工の手引 き, 2001 .

4) 地盤工学会 地盤設計・施工技術委員会編：地山補強 土工法設計・施工マニュアル, 171 p., 2011.

5) (独)労働安全衛生総合研究所 斜面崩壊による労働㷋 害の防止対策に関寸る調查研究会：「斜面崩壊によ る労働災害の防止対策に関する調查研究会」報告書, https://www.jniosh.go.jp/publication/houkoku/houkoku_20 10 01.html

6) 伊藤和也, 豊澤康男, Tamrakar S. B., 堀井宣幸 : 建 設工事中の斜面崩壊による労働災害の調查・分析, 日本地すべり学会誌, Vol. 41, No. 6, pp. 17-26, 2005.

7) 村松正重, 末岡徹, 龍岡文夫 : 地山補強土工法にお ける補強機構とのり面保護工の効果, 土木学会論文 集, Vol. 517/III-31, pp. 93-104, 1995.

8) 西村和夫, 山本稔 : 比較的短いロックボルトを用い た切り取り斜面の安定について, 土木学会論文集, No. 388/III-8, pp. 217-226, 1987.

9）山本稔, 佐藤恭介, 佐々木健二 : ボルトによる切土 斜面の安定に関する実験, 土木学会第 36 回年次学術 講演会, III-313, pp. 624-625, 1981.

10) 土質工学会（現地盤工学会）地盤工学における模型 実験入門編集委員会編 : 4.3.4 掘削過程の再現, 地盤 工学における模型実験入門, pp. 120-123, 1994.

11) Tei, K., Taylor, R. N., Milligan, G. W. E.: Centrifuge model tests of nailed soil slopes, Soils and Foundations, Vol. 38, No. 2, pp. 165-177, 1998.
12) Davis, M. C. R. and Jones, A. M.: Stability of a steep excavation retained by soil nails, Proc. of Centrifuge 98, pp. 773-778, 1998.

13) Kimura, T., Takemura, J., Hiro-Oka, A., Okamura, M. and Park., J. : Excavation in soft clay using in-flight excavator, Proc. of Centrifuge 94, pp. 649-654, 1994.

14) Loh, C. K., Tan, T. S. and Lee, F. H. : Three-dimensional excavation tests, Proc. of Centrifuge 98, pp. 649-654, 1998.

15) Laue, J. : Centrifuge technology. Constitutive geotechnical centrifuge technology: Two extremes, Ascona Workshop, 28 p., 2001.

16) Toyosawa, Y., Horii, N., Tamate, S., Suemasa, N. and Katada, T.: Failure mechanism of anchored retaining wall, Proc. of Centrifuge 98, pp. 667-672, 1998.

17) Derkx, F., Merliot, E., Garnier, J. and Cottineau, L. M.: Onboard remote-controlled centrifuge robot, Proc. of Centrifuge 98, pp. 97-102, 1998.

18) Ng, C. W. W., Van Laak, P. A., Zhang, L. M., Tang, W. H., Zong, G. H., Wang, Z. L., Xu, G. M. and Liu, S. H.: Development of a four-axis robotic manipulator for centrifuge modeling at HKUST, Proc. of ICPMG '02, pp. 71-76, 2002.

19）伊藤和也, 玉手聡, 豊澤康男, 堀井宣幸 : 新遠心模 型実験装置（NIIS-Mark II Centrifuge）の開発，産業安 全研究所研究報告, NIIS-RR-2005（2006）, pp. 57-74, 2006.

20) Oda, M., Koishikawa, I. and Higuchi, T.: Experimental study of anisotropic shear strength of sand by plane strain test, Soils and Foundations, Vol. 18, No. 1, pp. 25-38, 1978.

21) Sonnenberg, R., Bransby, M. F., Bengough, A. G., Hallett, P. D. and Davies, M. C. R.: Centrifuge modelling of soil slopes containing model plant roots, Canadian Geotechnical Journal, Vol. 49, pp. 1-17, 2012.

22) Ng, C. W. W., Kamchoom, V. and Leung, A. K.: Centrifuge modelling of the effects of root geometry on transpirationinduced suction and stability of vegetated slopes, Landslides, Vol. 13, pp. 925-938, 2016

23）舘山勝: 地山補強土工法の現状と課題, 特集 地山補 強土工法，基礎工，Vol. 34, No. 5, pp. 4-11, 2006.

24）吉川直孝：画像解析による局所変形計測法を用いた 砂質土の浅い基礎の支持力発現機構に関する研究, 山口大学博士論文, pp. 27-52, 2007.

25) 竿本英貴, 松島亘志, 山田恭央 : LAT-PIV 可視化実 験手法の開発と粒子一流体系一の応用, 応用力学論 文集, Vol. 8, 2005.

26）社団法人可視化情報学会 : PIV ハンドブック可視化情 報学会編，森北出版，pp. 68-75, pp. 119-122, 2002.

27) 田山聡, 緒方健治, 永吉哲哉, 竹内孝光 : 地山補強 土工法を用いた掘削斜面の変形計測による安定管理, 土木学会論文集, No. 644/VI-46, pp. 113-122, 2000.

(2018. 5. 31 受付) 


\title{
EXCAVATION OF SLOPE REINFORCED TEMPORARY BY SOIL NAILING USING IN-FLIGHT EXCAVATOR IN CENTRIFUGE
}

\author{
Kazuya ITOH, Taketo HAYASHI, Naotaka KIKKAWA, \\ Nobutaka HIRAOKA and Takeharu KONAMI
}

In Japan, there are approximately 30 to 40 slope failure accidents every year, causing injury to workers and damage to property. It has been reported that more than $50 \%$ of these accidents occurred during excavating or leveling the lower parts of the slope toe, indicating the necessity of developing a temporary and simple slope reinforced method to prevent such accidents during slope cutting works. Although many natural ground reinforced earth method for permanent have been developed to keep the stability of a steep cut slope, most of them are either difficult to set up under the construction or are too expensive to use at small to medium-sized slope cutting sites. In this study, as a simple and cost-effective slope reinforced method for small to medium-sized slope cutting sites, a temporary soil nailing was considered, and the reinforcing mechanism of soil nailing was investigated by centrifuge model tests. An in-flight excavator, which can excavate the model slope in high centrifuge acceleration environment, was used in this paper for simulating the slope cutting works. The deformation of mode slope during excavation was measured by PIV (Particle Image Velocimetry) and the deformation processes in the model slopes with and without the soil nailing were compared in the strain field. 